Politik Indonesia: Indonesian Political Science Review 1 (2) (2016) 136-153

Politik Indonesia

Indonesian Political Science Review

http://journal.unnes.ac.id/nju/index.php/JPI

\title{
Pembiaran Pada Potensi Konflik dan Kontestasi Semu Pemilukada Kota Blitar: Analisis Institusionalisme Pilihan Rasional
}

\author{
Moh. Fajar Shodiq Ramadlan ${ }^{1 凶}$, Tri Hendra Wahyudi ${ }^{1}$ \\ ${ }^{1}$ Universitas Brawijaya, Indonesia
}

\section{Info Artikel}

Sejarah Artikel:

Diterima 31 Maret 2016

Disetujui 15 Juni 2016

Dipublikasi 15 Juli 2016

Keywords:

Local Election; Conflict

Managemen; Pseudo-

Contestation; Avoiding

\begin{abstract}
Abstrak
Pemilukada serentak merupakan langkah baru dalam demokratisasi di Indonesia. Melihat pengalaman penyelenggaraan Pemilukada di banyak daerah yang berpotensi menimbulkan konflik dan kerusuhan, manajemen konflik diperlukan guna mengantisipasi potensi konflik. Artikel ini menjelaskan manajemen konflik pemilukada di Kota Blitar menggunakan pendekatan kelembagaan pilihan rasional, dengan asumsi bahwa lembaga-lembaga yang terkait dengan penyelenggaraan pemilu mempunyai kemampuan dalam manajemen konflik. Kota Blitar dipilih karena mempunyai aspek yang parikular dimana terdapat dua kandidat, yakni petahana dan perseorangan, tetapi dengan kontestasi yang bersifat semu. Artikel ini merupakan hasil penelitian kualitatif eksploratif. Teknik penggalian data adalah dengan focus group discussion yang melibatkan lembaga-lembaga terkait pemilukada di Kota Blitar. Melalui penelitian ini, ditemukan bahwa meskipun institusi terkait pemilukada memahami potensi konflik, tetapi manajemen konflik yang dipilih adalah metode pembiaran.
\end{abstract}

\begin{abstract}
The simultaneous local election is the new step of democratization in Indonesia. Viewing an implementation about the local election in each district which have many of potential conflict and unrest, conflict managements required to anticipate a potential conflict. This paper will suggest to describe about conflict management of the local election in Blitar City using an rational choice institutionalism approach, assuming that institutions has a capacity to solve a problem of conflict management in the local election. Blitar city been selected because it has a particular aspect that the two candidates, namely by incumbent and independent, but the contestation is pseudocontestation. This paper is the result of exploratory qualitative research. The techniques to explore data is use focus group discussion that involved an institutions related with Blitar local election. Belong this research, the institutions that related in the local elections understand a potential conflict, but the selected conflict management is avoiding method.
\end{abstract}

(C) 2016 Universitas Negeri Semarang 


\section{Pendahuluan}

Pemilukada langung serentak menjadi langkah baru dalam demokratisasi di Indonesia. Setelah debat panjang di DPR untuk menentukan apakah tetap diselenggarakan pemilukada atau mengembalikan pemilihan kepala daerah ke DPRD, yang salah satu pertimbangannya adalah besarnya biaya penyekenggaraan pemilukada, maka pemilukada serentak merupakan jalan tengah untuk tujuan jangka panjang untuk menciptakan pemilihan kepala daerah yang lebih efektif dan efisien. Keputusan untuk melaksanakan pemilukada serentak memang baru disahkan pada tahun 2015, dan gelombang pertama pemilukada serentak akan dimulai pada bulan Desember 2015 di 271 daerah yang masa jabatan kepala daerahnya berakhir pada 2015 dan semester I2016. Gelombang kedua pemilukada diadakan pada Februari 2017 untuk kepala daerah yang akhir masa jabatan semester II-2016 dan 2017. Gelombang ketiga pemilukada diadakan pada Juni 2018 untuk AMJ 2018 dan 2019. Adapun pemilukada serentak nasional disepakati diadakan pada 2027.

Pengalaman penyelenggaraan

pemilukada di Indonesia bukan tanpa pengalaman konflik dan kerusuhan. Sejak diselenggarakan pertama kali pada Juli 2005, tak kurang dari 1.027 pemilukada diselenggarakan di negeri ini. Tahun 2012, dilaksanakan 73 pemilukada (enam pemilihan gubernur dan 67 pemilihan bupati/wali kota). Data Sistem Nasional Pemantauan Kekerasan
(SNPK) Indonesia menunjukkan sejak tahun 2005 hingga 2014, di seluruh wilayah Indonesia, terjadi 2570 konflik terkait pemilihan dan jabatan, dalam berbagai bentuk konflik dan tersebar di seluruh Indonesia. Dua tahun pertama penyelenggaraan Pemilukada (2005-2007), setidaknya terdapat 98 dari 323 daerah yang menyelenggarakan Pemilukada dirundung persoalan. Tak kurang dari penyelenggaraan 21 Pemilukada berakhir bentrokan dan kerusuhan. (Kompas. 28 Juni 2013).

Dalam kaitan itu, setidaknya ada 5 (lima) sumber konflik potensial, baik menjelang, saat penyelenggaraan, maupun pengumuman hasil Pemilukada. Pertama, konflik yang bersumber dari mobilisasi politik atas nama etnik, agama, daerah, dan darah. Kedua, konflik yang bersumber dari kampanye negatif antar pasangan calon kepala daerah. Ketiga, konflik yang bersumberdari premanisme politik dan pemaksaan kehendak. Keempat, konflik yang bersumber dari manipulasi dan kecurangan penghitungan suara hasil Pemilukada. Kelima, konflik yang bersumber dari perbedaan penafsiran terhadap aturan main penyelenggaraan Pemilukada (Haris, 2005). Kelima sumber konflik tersebut juga menjadi potensi konflik penyelenggaraan Pemilukada serentak di berbagai daerah. Dalam konteks tersebut, kebutuhan atas kapasitas mengelola konflik pemilukada menjadi penting.

Kota Blitar merupakan salah satu daerah yang menyelenggarakan pemilukada 
pada Desember 2015. Pemilukada di Kota Blitar, diikuti oleh dua pasangan kandidat, yakni calon incumbent Samanhudi AnwarSantoso, yang diusung koalisi Partai Demokrasi Indonesia Perjuangan (PDI-P), Partai Nasional Demokrat (Nasdem), Partai Gerakan Indonesia Raya (Gerindra), Partai Keadilan Sejahtera (PKS), Partai Golongan Karya (Golkar), Partai Hati Nurani Rakyat (Hanura), Partai Amanat Nasional (PAN), dan Partai Demokrat. Calon petahana Samanhudi Anwar adalah Wali Kota Blitar, yang sebelumnya menggantikan Djarot Syaiful Hidayat yang kemudian menjabat sebagai wakil gubernur DKI Jakarta. Sedangkan wakilnya Santoso adalah mantan Sekretaris Daerah Kota Blitar. Calon kedua adalah Muhsin-Dwi Sumardiyanto, yang maju sebagai kandidat walikota dari jalur perseorangan.

Yang perlu dikritisi dalam konteks pemilukada kota Blitar, sekaligus argumen mengapa Kota Blitar dipilih sebagai obyek penelitian adalah, kandidat perseorangan (independent) sebenarnya merupakan "kandidat boneka" dari petahana (incumbent). Proses pendaftaran kandidat perseorangan relatif sangat rapi, detail dan tanpa kendala yang berarti, serta mencukupi persyaratan untuk menjadi calon independen. Padahal, jika merujuk pada Undang-undang nomor 8/2015 tentang Pemilihan Umum Kepala Daerah dan Wakil Kepala Daerah, prasyarat calon independen sangat berat dan mempersulit aspek administratif pendaftaran calon perseorangan. Calon perseorangan mensyaratkan calon yang benar-benar populer, didukung oleh akar rumput, dan mempunyai kemampuan logistik dan keuangan yang mumpuni. Karena itu, kontestasi yang terjadi adalah kontestasi semu (pseude-contestation)

Gambaran tersebut menjadikan kontestasi dalam pemilukada Kota Blitar relatif berintensitas rendah, atau tidak terjadi kompetisi yang ketat. Banyak pihak, baik pemerintah, partai politik, penyelenggara pemilu bahkan masyarakat, berpersepsi bahwa pemilukada Kota Blitar sudah dapat diprediksi siapa yang akan menjadi pemenang. Kondisi ini juga menjadikan banyak stakeholder menjelang dilaksanaknnya Pemilukada Kota Blitar menilai bahwa Pemilukada Kota Blitar akan berlangsung minim konflik.

$$
\text { Salah seorang kandidat yang }
$$
diprediksi menjadi pemenang, Samanhudi, juga mengungkapkan bahwa Pemilukada kota Blitar akan berlangsung sangat kondusif. Bahkan nuansa permusuhan baik di tingkat pasangan calon maupun pendukung disebutnya sama sekali tak ada. Ia mengungkapkanbahwa setiap pagi ia sarapan bersama calon lawan. Fenomena ini menunjukkan bahwa Pemilukada Kota Blitar merupakan kontestasi "semu". Dalam kontestasi semu inilah, menarik melihat model manajemen konflik yang dipilih oleh berbagai stakeholder di dalam pemilukada.

Artikel ini hendak menjelaskan bagaimana para stakeholder terkait 
penyelenggaraan pemilukada di Kota Blitar melihat potensi konflik yang terjadi menjelang pemilukada. Kedua, artikel ini hendak menjelaskan model yang digunakan dalam manajemen konflik dalam konteks kontestasi "semu" pada pemilukada di Kota Blitar. Artikel ini memberi sumbangsih dalam kajian pengelolaan konflik pemilukada terutama dalam pilihan-pilihan model yang digunakan oleh stakeholder di daerah dalam pelaksanaan Pemilukada melalui perspektik institusionalisme pilihan rasional.

\section{Kajian Pustaka}

Metodologi

Penelitian ini menggunakan teknik Focus Group Discussion (FGD) atau Diskusi Kelompok Terarah dalam penggalian data. Dalam teknik FGD, aktor atau kelompok yang terkait, yang menjadi informan, di kumpulkan pada satu forum, untuk saling berinteraksi, berdiskusi, dan saling membantah atau menguatkan tentang suatu persoalan atau topik spesifik, dengan dipandu oleh fasilitator atau mediator (Somekh and Lewin, 2011: 215)

Teknik ini dipilih karena dapat mempertemukan dan terjalin komunikasi intra dan antar pihak terkait pemilukada Blitar, mulai penyelenggara pemilu, partai politik hingga pemerintah. Melalui pertemuan pada satu forum, dapat diidentifikasi cara pandang yang berbeda terhadap pemahaman, pemaknaan, penafsiran suatu masalah, berdasarkan latar belakang dan kepentingan.
Hasil FGD ditranskrip, di-koding, ditabulasi untuk kemudian dianalisis

\section{Pendekatan Institusionalisme Pilihan Rasional}

Akar ilmu politik adalah pada studistudi tentang lembaga, tentang kelembagaan negara, birokrasi, kebijakan publik, yang kesemuanya dilihat dalam kerangka kelembagaan. Tetapi pada periode pascaPerang Dunia II, disiplin ilmu politik, terutama di Amerika Serikat, telah mengkritik studi tentang lembaga-lemabaga tersebut dengan berkembangnya dua pendekatan yang lebih didasarkan pada asumsi individualistik: behavioralisme dan pilihan rasional. Kedua pendekatan ini mengasumsikan bahwa individu bertindak secara otonom sebagai individu, baik berdasarkan karakteristik sosiopsikologis atau perhitungan rasional untung rugi oleh individu. Dalam kedua teori, individu tidak dibatasi oleh baik lembaga formal maupun informal, tapi akan membuat pilihan mereka sendiri. Faktor individu dipandang lebih determinan dalam prosesproses berjalannya lembaga-lembaga negara, serta pada keputusan-keputusan politik (Peters, 1999: 25). Hal ini merupakan titik tolak dari perkembangan pendekatan "newinstitutionalism" atau pendekatan institusionalisme baru.

Tahun 1980-an, perhatian terhadap lembaga formal dan non-formal pada sektor publik dan bagaimana peran penting struktur, mulai tumbuh kembali. Penjelasan 
kelembagaan digunakan dalam studi kebijakan dan tata kelola pemerintahan, tetapi juga memperhatikan perilaku pada tingkat individu.

Pendekatan institusionalisme baru mencerminkan banyak vitur dari versi lama dari pendekatan institusionalisme untuk memahami politik, di samping, juga memberi kemajuan pada studi politik pada sejumlah teori dan analisis empiris. Sebagai contoh: "institusionalisme lama" sistem presidensial secara signifikan berbeda degan sistem parlementer berdasarkan struktur formal dan aturan. Pendekatan "institusionalisme baru", melihat lebih jauh dan mencoba untuk mecari tahu apakah perbedaan-perbedaan tersebut benar-benar berbeda, dan jika demikian, bagaimana mengatur kehidupan politik yang berbeda tersebut? Apakah perbedaan tersebut lantas juga menciptakan perbedaan dalam hal kinerja pemerintah? (Peters, 1999: 25). Pertanyaan-pertanyaan kritis tersebut, lebih jauh, juga merefleksikan bahwa pendekatan insitusionalisme baru juga melihat bagaimana sebuah sistem, struktur, atau lembagalembaga tersebut direkayasa dan berintraksi sedemikian rupa untuk mencapai tujuan tertentu.

Hall dan Taylor (1996: 9) membagi pendekatan institusionalisme baru ke dalam tiga kelompok teori, yaitu institusionalisme historis (historical institutionalism), institusionalisme pilihan rasional (rational choice institutionalism) dan institusionalisme sosiologis (sociological instituti $\neg$ onalism).
Dalam arikel ini, kami menggunakan pendekatan institusionalisme pilihan rasional dalam menjelaskan relasi kelembagaan dan manajemen konflik dalam pemilukada.

Institusionalisme pilihan rasional berawal dari studi tentang perilaku kongres di Amerika, dimana terdapat perbedaan yang beragam dan tajam terhadap preferensi dan karekteristik legislator mengenai kebijakan. Tetapi meski terjadi perbedaan yang tajam, kongres masih menunjukkan situasi yang cukup stabil. Fenomena ini memunculkan pertanyaan bagaimana institusi dengan perbedaan yang tajam masih dapat berjalan dengan stabil. Salah satu penjelasannya adalah adanya transaksi atau tawar menawar di antara para legislator dalam perumusan atau kesepakatan terhadap kebijakan tersebut. Teradapat proses-proses politik berdasarkan pertimbangan untung rugi untuk menyelesaikan masalah-masalah bersama (Hall dan Taylor, 1996: 9). Institusionalisme pilihan rasional melihat proses institusionalisasi dan relasi antar institusi sebagai mekanisme untuk menyelesaikan persoalan bersama melalui pertimbanganpertimbangan rasional dan untung rugi.

Dalam pandangan institusionalisme pilihan rasional-seperti halnya teori pilihan rasional-manusia secara individual-yang juga merupakan representasi dar sebuah institusidipandang sebagai individu rasional yang bertindak atas dorongan kepentingan rasional, didasari oleh perhitungan ekonomis, untungrugi, memaksimalkan keuntungan dan aksi- 
reaksi dari aktor lainnya. Asumsi mendasar dari institusionalisme pilihan rasional adalah bahwa individu adalah aktor sentral dalam proses politik, dan bahwa orang-orang bertindak rasional untuk memaksimalkan utilitas pribadi. Salah satu mencapai tujuan tersebut secara efektif adalah melalui tindakan institusional, dan perilaku mereka juga dibentuk oleh lembaga (Peters, 1991: 45). Tindakan individu mempengaruhi lembaga, tetapi juga diatur oleh aturan-aturan dalam lembaga. Karena itu, tindakan atau keputusan lembaga, juga dapat merefleksikan tindakan individu.

Institusionalisme pilihan rasional melihat keseimbangan institusional sebagai norma atau aturan-baik formal maupun informal-yang disepakati bersama. Pendekatan ini melihat bahwa keadaan normal politik adalah di mana aturan permainan yang stabil dan para aktor memaksimalkan keuntungan (biasanya keuntungan pribadi) yang diberikan oleh aturan-aturan tersebut. Para aktor mempelajari aturan-aturan, strategi adaptasi dan dengan demikian melahirkan keseimbangan institusional. Meski tidak semua aktor merasa senang atau diuntungkan dengan struktur kelembagaan yang terbentuk, tetapi yang menjadi tujuan adalah pada kondisi yang stabil. Setelah stabil, sangat sulit untuk mengubah aturan karena tidak ada yang bisa memastikan hasil dari struktur yang terbentuk (Clarke and Foweraker, 2005: 572).

Ada beberapa fenomena yang menjadi perhatian para penganut pilihan rasional institusionalisme, termasuk analisis dalam perilaku koalisi, pengembangan lembagalemabga politik dan kajian tentang konflik (Hall dan Taylor, 1996: 9). Dalam konteks penelitian ini, pendekatan institusionalisme baru digunakan dalam melihat bagaimana lembaga-lembaga berperan dan merespon perubahan-perubahan yang menuntut peran mereka. Serta, bagaimana aktor-aktor dalam lemabga, atau aktor-aktor yang merefleksikan lembaga, berfikir, dan berperan. Baik peran yang diatur dan dibatasi oleh norma dan aturan, maupun peran yang lebih luas yang tidak diatur dalam aturan-aturan formal.

\section{Konflik Pemilukada}

Konflik secara umum didefinisikan sebagai suatu situasi dimana dua pihak atau lebih berusaha untuk mendapatkan sumber daya yang sama langka di sama waktu (Wallensteen, 2002: 16). Para sarjana sosial umumnya setuju bahwa lebih dari satu pihak agar sebagai prasyarat terjadinya konflik dan faktor waktu dinilai penting. Penyebab utama adalah sumber daya yang langka. Sumber daya bukan sekedar soal sumber ekonomi di alam, tetapi juga berkaitan dengan orientasi ekonomi, keamanan manusia, lingkungan, isuisu sejarah, dll. Dalam konteks politik, jabatan atau posisi strategis dalam institusi politik, juga dapat dilihat sebagai sumber daya yang terbatas.

Simon Fisher (2000: 6) menyatakan bahwa konflik merupakan keniscayaan, tak terhindarkan dan kerap bersifat reatif. Konflik 
dapat terjadi ketika tujuan masyarakat tidak sejalan, berbagai pendapat dan konflik bisa diselesaikan tanpa terjadi kekerasan. Dalam perspektif hubungan masyarakat, Fisher menjelaskan bahwa bahwa konflik disebabkan oleh terjadinya polarisasi sosial, serta kondisi dimana tidak adanya saling rasa percaya dalam masyarakat, yang akhirnya melahirkan permusuhan diantara kelompok yang berbeda dalam suatu masyarakat. selain itu, penyebab konflik dalam masyarakat juga dapat disebabkan oleh kebutuhan-kebutuhan dasar manusia.

Sejalan dengan Fisher, T.F. Hoult (dalam Wiradi, 2000) menyebut konflik merupakan proses interaksi antara dua (atau lebih) orang atau kelompok yang masingmasing memperjuangkan kepentingannya atas obyek yang sama, yaitu sumber daya (dijelaskan tanah dan benda-benda lain yang berkaitan dengan tanah, seperti air dan perairan, tanaman, tambang, dan juga udara yang berada di atas tanah yang bersangkutan). Konflik yang terjadi dapat berupa konflik vertikal, yaitu antar pemerintah, masyarakat dan swasta, antar pemerintah pusat, pemerintah kota dan desa, serta konflik horizontal yaitu konflik antar masyarakat.

Konflik pemilukada, merupakan konflik politik, dan konflik politik dapat digolongkan dalam konflik sosial, terjadi di antara anggota masyarakat sebagai akibat dari adanya hubungan sosial yang cukup intensif. Konflik politik berkaitan dengan penguasa politik atau keputusan yang dibuatnya (keputusan politik). Masalah yang dipertentangkan dalam konflik politik berada pada tingkatan political (Urbaningrum, 1999). Penjelasan di atas sejalan dengan konteks pemilukada serentak, yang secara substansi adalah kompetisi dan konflik. Terjadi polarisasi di antara kelompok masyarakat dalam memperebutkan sumber daya yang terbatas, dan pada banyak kasus melahirkan konflik vertikal dan horizontal. Meski kompetisi dan konflik dalam pemilukada jika terkelola akan menjadi celah positif bagi perkembangan masyarakat, tetapi bukan proses yang mudah. Dibutuhkan kerjakerja yang signifikan dalam mengelola konflik sosial agar mengarah pada pengkondisian situasi positif dimasyarakat.

\section{Manajemen Konflik Pemilukada}

Dalam pandangan fungsional, konflik sebenarnya dapat dikelola. Manajemen konflik dapat dipahami sebagai rangkaian aksi dan reaksi antara pelaku dan pihak luar dalam konflik. Manajemen konflik mengacu pada pendekatan untuk mengarahkan pada bentuk komunikasi dan tingkah laku dari pelaku maupun pihak luar dalam konflik bagaimana mereka mempengaruhi kepentingan mereka. Manajemen konflik tidak hanya dipahami sebagai upaya mengenali konflik dan menganalisa agar konflik dapat dikontrol tetapi juga dipahami sebagai gagasan, teori dan metode untuk memahami konflik dan praktik kolektif untuk mengurangi potensi 
kekerasan dan meningkatkan harmonisasi dalam proses politik.

Selama ini, kritik yang berkembang dalam manajemen konflik di banyak kasus konflik sosial di Indonesia, model manajemen konflik cenderung dilakukan dengan cara parsial dan dengan cara dibentuk sedemikian rupa (ad hoc). Akibatnya kurang menyentuh jantung dan akar penyelesaian konflik jangka panjang. Di banyak kasus, penyelesaian konflik dimulai dengan penghentian konflik melalui cara-cara koersif oleh pihak keamanan (peace keeping) kemudian dilanjutkan dengan penetapan serangkain aturan termasuk sanksi bagi semua pihak agar tidak mengulangi konflik (Suprapto, 2013).

Salah satu model manajemen konflik adalah dual concern model atau model kepedulian ganda. Model ini merupakan salah satu model manajemen konflik paling sederhana, yang dikembangkan oleh Blake dan Mouton (1964) dan dikembangkan oleh sarjana lain, salah satunya adalah Thomas (1976) dan Pruitt \& Rubin (1986). Model ini bertolak dari pertanyaan apakah seseorang atau kelompok memiliki kepedulian terhadap pihak lain dan apakah pemilihan strategi menyelesaikan masalah akan efektif dalam situasi atau persoalan tertentu. Terdapat lima strategi manajemen dan resolusi konflik menurut model kepedulian ganda (Cai and Fink, 2002), yakni:

1. Integrating style: strategi manajemen konflik ini ditandai dengan kesediaan pihak-pihak yang berkonflik untuk saling berkomunikasi secara terbuka, untuk mengatasi perbedaan secara konstruktif dan berupaya merumuskan solusi yang dapat saling diterima. Model ini mengharapkan win-win solution, dimana semua pihak merasa diuntungkan atau mengalami kerugian minimal.

2. Obliging style: strategi ini terjadi jika kepedulian terhadap kepentingan sendiri rendah dan kepedulian terhadap kepentingan orang lain tinggi. Gaya ini bersifat non-konfrontatif, menekankan untuk menjaga hubungan dengan orang lain daripada mengejar hasil untuk kepentingan diri sendiri. Strategi ini akan efektif dalam kondisi pihak yang memiliki kepedulian adalah pihak yang kuat dan dominan.

3. Dominating style: strategi ini merupakan yang paling konfrontatif, yang lebih mementingkan kepentingan diri sendiri daripada kepentingan orang lain. Manajemen konflik menggunakan strategi ini ditandai dengan upaya atau taktik intimidatif, ejekan, dan berfokus untuk mengalahkan lawan.

4. Avoiding style: strategi ini berarti upaya menghindari atau membiarkan masalah. Strategi ini merupakan gaya nonkonfrontatif. Untuk jangka waktu tertentu atau persoalan tertentu, cara ini efektif, tetapi dapat menjadi persoalan besar jika berakumulasi menjadi persoalan yang lebihh besar dalam waktu jangka panjang. 
5. Compromising style: gaya ini
mencerminkan pihak-pihak yang berkonflik berupaya untuk mengejar hasil yang dapat diterima bersama untuk mencapai hasul yang optimal. Cara ini efektif pada situasi yang tidak ada tekanan, waktu yang terbatas, atau besarnya biaya jika konflik berlarut.

Dalam artikel ini, upaya keempat, yakni avoiding style, yang akan diulas karena menjadi pilihan mengelola konflik oleh aktor dan institusi terkait Pemilukada Kota Blitar.

\section{Eksplorasi Persepsi Stakeholder tentang}

\section{Potensi Konflik}

Bagian ini akan mengulas bagaimana pemahaman, persepsi dan interpretasi masingmasing stakeholder atau actor/institusi yang peneliti libatkan dalam FGD tentang potensi konflik, upaya mengelola konflik, dan persepsi mereka tentang kondisi politik menjelang Pemilukada Kota Blitar. Melalui pemetaan persepsi soal potensi konflik, serta berkaitan dengan hambatan-hambatan yang dirasakan oleh aktor atau institusi terkait Pemilukada kota Blitar.

Secara sederhana, pemetaan perspektif para stakeholder terkait potensi dan upaya mengelola konflik pemilukada di Kota Blitar dapat dilihat pada tabel berikut:
Tabel 1. Perspektif Stakeholder tentang Manajemen dan Potensi Konflik Pemilukada di Kota Blitar

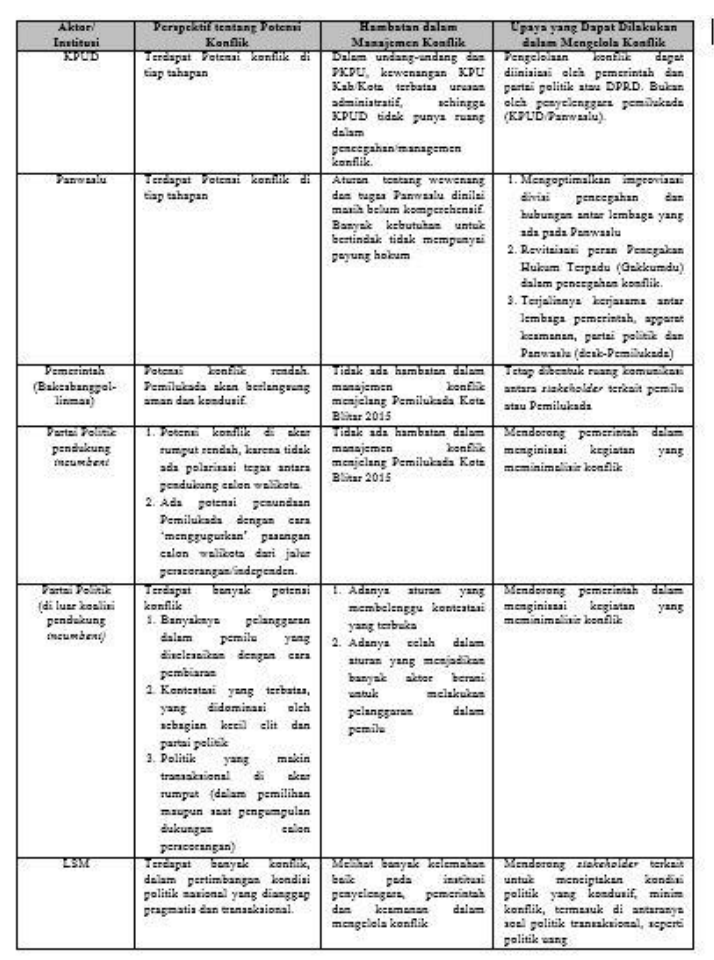

Penyelenggara pemilu, yakni KPUD dan Panwaslu Kota Blitar menyadari sepenuhnya dan bahkan khawatir, jika terjadi persoalan terkait penyelenggaraan pemilu, maka yang menjadi sasaran utama kesalahan adalah penyelenggara pemilu. Dalam konteks pra-pemilu, baik KPUD dan Panwaslu masih menyadari bahwa tiap tahapan dalam Pemilukada mempunyai potensi konflik. Bahkan persoalan pada satu tahapan, akan turut mengganggu tahapan selanjutnya. Potensi konflik pada aspek yang mendasar, misalnya, persoalan Daftar Pemilih Tetap (DPT), dapat menjadi alat mendelegitimasi proses penyelenggaraan pemilu. Tidak hanya pada pelaksanaan pemungutan suara, tetapi juga pada penetapan pemenang Pemilukada. 
Potensi konflik yang menurut KPUD dan Panwaslu penting untuk dicermati adalah pada penerimaan hasil pemilu. Tetapi dalam konteks pemilukada Kota Blitar, hasil pemilu bukan menjadi masalah utama. Semua stakeholder menyadari kandidat mana yang akan menjadi pemenang - seperti yang sudah dijelaskan pada bagian pendahuluan sebelumnya.

Meski menyadari terdapat potensi di tiap tahapan pemilu, KPUD dan Panwaslu merasa bahwa ruang gerak mereka juga terbatas karena mereka juga merupakan lembaga birokratis yang harus patuh terhadap prosedur dan aturan. Hal ini yang menjadi hambatan KPUD dan Panwaslu dalam mengambil langkah lebih luas untuk mengelola konflik. Salah satu perkembangan dalam hal ruang gerak dirasakan oleh Panwaslu dengan dikeluarkanya Peraturan Bawaslu No 7 Tahun 2015 yang menambah dan mengatur adanya divisi pencegahan dan hubungan antar lembaga pada organisasi Panwaslu. ${ }^{66}$

Persepsi soal potensi konflik pilada oleh pemerintah Kota Blitar, justru berbeda dengan persepsi penyelenggara pemilu. Persepsi bahwa penyelenggaraan Pemilukada di Kota Blitar akan berlangsung aman dan tanpa konflik, lebih banyak diungkapan oleh pemerintah Kota Blitar (dalam hal ini, yang

\footnotetext{
${ }^{66}$ Meski demikian, bagaimana pelaksanaan peran pada divisi pencegahan dan hubungan antar lemabaga pada Pemilukada Kota Blitar Desember 2015 lalu, belum dipahami dan diterapkan secara teknis dan spesifik, mengingat aturan bawaslu No. 7 Tahun 2015 merupakan aturan baru.
}

saat itu terlibat dalam FGD adalah Bakesbangpollinmas). Persepi tersebut, selain karena kontestasi dalam pemilukada Kota Blitar tidak terlalu kompetitif, pemerintah mengklaim Kota Blitar selama ini, baik secara sosial dan kultur, dirasa aman dan minim konflik dalam penyelenggaraan pemilu apa pun.

Persepsi terhadap potensi konflik yang lebih beragam justru disampaikan oleh partai politik. Meski sebagian partai politik juga menyadari kandidat mana yang mempunyai peluang menang paling besar bahkan sebagian di antara parpol di Kota Blitar mengungkapkan bahwa pemenang Pemilukada Kota Blitar sudah dapat diketahui sebelum pelaksanaan Pemilukada dimulai tetapi mereka menyadari bahwa terdapat beberapa hal yang dapat menjadi potensi konflik Pemilukada di Kota Blitar. Pandangan tersebut, tidak lepas karena partai politik merupakan institusi yang di dalamnya berisi aktor-aktor yang terlibat langsung dengan politik di Kota Blitar dalam jangka waktu yang relatif lebih panjang, dibandingkan dengan aktor yang ada di KPUD, Panwaslu, bakesbangpol dan kepolisian. Karena itu, sebagian pandangan mereka di satu sisi merefleksikan kesadaran, pehamanan dan pengalaman pemilu di masa lalu di Kota Blitar, serta kemugkinan-kemungkinan yang terjadi pada pemilu mendatang.

Partai politik menilai, di beberapa momen pemilu di Kota Blitar, terdapat persoalan dalam penyelenggaraan 
Pemilukada, tetapi partai politik melihat persoalan tersebut ditangani dengan mekanisme "pembiaran". Persoalan pembiaran tersebut terjadi karena model politik yang lebih mengarah pada politik transaksional. Beberapa persoalan tidak dilakukan melalui jalur hukum, atau, beberapa pelanggaran memang sudah dikalkulasi implikasi hukum pada pelanggaran tersebut. Fenomena ini, yang menurut partai politik menjadi salah satu sebab pelanggaran dalam pemilu dilakukan melalui model pembiaran.

Partai politik juga mengeluhkan penegakan aturan dan netralitas penyelenggara pemilu. Partai politik melihat terdapat kecenderungan pada kandidat dan partai politik yang dominan dalam pemerintahan untuk mengintervensi pemerintahan atau birokrasi, serta penyelenggara pemilu. Meski demikian, kecenderungan ini dianggap "lumrah" oleh partai politik, karena kecenderungan kelompok yang berkuasa berupaya untuk menguasai seluruh instrument kekuasaan, termasuk pada aspek pemilu.

Persoalan yang sebenarnya menjadi sorotan utama, terutama oleh partai politik di Kota Blitar yang tidak sepenuhnya terlibat dalam kontestasi Pemilukada Desember 2015, adalah soal struktur aturan yang tidak membuka peluang partisipasi dan kompetisi yang lebih luas. Adanya aturan yang dirasa membelenggu oleh partai kecil di daerah, karena kader dari partai mereka dipaksa berkoalisi dengan kader dari partai lain. Selain itu, dalam konteks pemilukada Kota Blitar, struktur aturan yang mensyaratkan syarat minimal, menjadi refleksi pandangan kritis partai politik terkait kondisi pemilukada di Kota Blitar yang didominasi oleh partai dan kandidat tertentu.

\section{Pembiaran pada Potensi Konflik: Sebuah} Pilihan Rasional

Konflik adalah hal yang inheren di dalam pemilukada, mengingat pemilukada adalah ajang kontestasi politik yang melibatkan banyak anasir kepentingan di masyarakat. Dengan demikian, alih-alih menghindari konflik, yang terpenting adalah bagaimana menyiapkan segenap penyelenggara Pemilukada agar memiliki kapasitas mumpuni ketika berhadapan dengan konflik, baik yang latent maupun ketika sudah bertransformasi faktual.

Dalam pemilukada, sensitivitas penyelenggara diuji dalam menghadapi konflik, itulah mengapa keterlibatan Kepolisian dan Pemerintah Daerah mutlak diperlukan. Mengingat, pertama, KPUD dan Panwaslu adalah dua badan ad hoc yang masa jabatannya sangat berbatas, sehingga keterlibatan dan pengalaman mereka dalam situasi konfliktual pemilukada sebelumnya relatif minimal. Kedua, penyelenggara pemilukada tidak dilengkapi dengan tupoksi yang berkaitan dengan deteksi potensi konflik, pun ihwal otoritas pengelolaan konflik tidak diatur dalam UU nomor 15/2011 tentang Penyelenggara Pemilihan Umum. Dengan 
demikian sensitivitas serta keterampilan menggali informasi mencegah konflik, tidak dimiliki penyelenggara Pemilu. Hal inilah yang mengharuskan penyelenggara pemilu dalam hal pengelolaan konflik - tidak bisa lepas dari peran kepolisian dan pemerintah daerah.

Sebagian partai politik kecil di Kota Blitar (yang oposisi dengan partai dominan) melihat penyelenggara pemilu dan pemerintah daerah lebih nampak sebagai bagian dari aktor yang melakukan pembiaran terhadap potensi konflik daripada pihak yang semestinya menjadi mediator. Parpol-parpol kecil (selain parpol pendukung petahana) menengarai adanya indikasi ketidaknetralan penyelenggara pemilu, bukan soal adanya dugaan transaksional, melainkan penyelenggara pemilu enggan menjadi inisiator pemecah potensi masalah dan masalah yang timbul dalam tahapan pemilukada.

Hal diatas juga diakui oleh Ketua Panwaslu Kota Blitar, diantaranya dalam kasus daftar pemilih perseorangan (DPS). Salah satu kasus adalah terkait beberapa pemilih purnawirawan TNI dan Polisi. Secara normatif, semestinya Panwaslu menjadi pihak yang mendorong para purnawirawan ini dipastikan namanya ada dalam DPS, melalui mekanisme rekomendasi. Tetapi panwaslu lebih memilih wait and see, karena menurutnya proses perbaikan DPS masih cukup panjang dan masih banyak cara kalaupun hingga finalisasi DPS nama-nama purnawirawan tersebut belum masuk.

Institusi-institusi terkait pemilukada baik kontestastan dan penyelenggara - sudah menerka, berhitung dan memprediksi bagaimana dan sejauh apa pelanggaran, kecurangan atau cacat dalam prosedur tidak bertentangan dengan aspek hukum. Terdapat kesamaan cara berpikir antara penyelenggara pemilukada dengan partai dominan yang berpeluang besar memenangkan pemilukada, yakni potensi konflik yang ada sebaiknya diabaikan saja, karena lambat laun akan selesai dengan sendirinya. Namun demikian, di balik pengabaian konflik oleh partai dominan, sebenarnya ada skenario tersembunyi yakni memudahkan agenda proses pemilu dan pemenangan kandidat tertentu.

Alasannya, semakin sedikit potensi konflik yang masuk ke ranah penanganan KPUD/Panwaslu (misalnya; kasus DPT dan sengketa pencalonan walikota) maka potensi gugatan yang masuk ke PTUN, sengketa proses di Bawaslu ataupun sengketa hasil di MK akan bisa diminimalisir. Jika sengketa semacam itu muncul, penyelenggara Pemilukada (KPUD/Panwaslu) harus bekerja lebih ekstra; melakukan investigasi, membuat klarifikasi, menyusun laporan dan keterangan tertulis, dan tindakan lain sebagai konsekuensi hukum posisi mereka sebagai pihak teradu atau pihak terkait. Di sinilah titik temu simbiosis antara penyelenggara pemilukada dengan partai dominan dimungkinkan, sama- 
sama diuntungkan jika proses pemilukada berjalan lancar. Kesamaan cara berpikir demikian yang memungkinkan lahirnya konsensus dari para pihak yang punya berbagai kepentingan. Konsensus tersebut bisa saja terwujud dengan atau tanpa proses yang transaksional.

Di samping itu, dengan berlindung di balik kekosongan norma hukum, Panwaslu bisa berada di zona nyaman tanpa harus mengambil tanggungjawab pencegahan/ penyelesaian konflik. Posisi ini bagi mereka menjadi alasan, bahwa kesan ketidaknetralan penyelenggara pemilu dalam kasus-kasus yang berpotensi konflik bukan karena penyelenggara pemilu berpihak, melainkan ketiadaan otoritas menyelesaikan konflik membuat pilihan membiarkan konflik itu menjadi pilihan yang benar dan taat asas.

Strategi pembiaran konflik seperti yang terjadi dalam pemilukada Kota Blitar, sebenarnya bukan langkah dalam managemen konflik yang ideal. Bahwa kemudian model pembiaran ini menjadikan potensi konflik reda dengan sendirinya, bukanlah sebuah langkah maju. Alih-alih menyelesaikan masalah, pembiaran ini sejatinya akan menimbulkan masalah besar jika kekuatan politik antara penantang dengan petahana relatif setara. Dinamika konfliktual yang berujung situasi 'damai' ini lebih disebabkan oleh faktor lain di luar kendali penyelenggara Pemilu, Pemerintah Daerah dan kepolisian. Diantaranya, (1) paragmatisme para aktor politik di luar kubu petahana, sehingga mendiamkan kecurangan-kecurangan politik adalah hal yang dianggap lumrah, (2) rendahnya soliditas di antara partai politik di luar koalisi-yang dibangun PDIP Kota Blitar, sehingga manuver pencalonan incumbent tidak mendapatkan perlawanan yang berarti, (3) lemahnya posisi NGO pemantau pemilu, sehingga laporan-laporan perihal kecurangan pencalonan kepala daerah hanya menjadi dokumen internal lembaga, tidak berujung gugatan ke Panwaslu/KPUD.

Dari perspektif peserta pemilukada, pembiaran konflik yang dilakukan oleh penyelenggara pemilukada akan mendorong aktor politik yang dominan memiliki skenario sendiri dalam penyelesaian potensi konflik. Sehingga dinamika kepemiluan akan terpisah menjadi dua aspek, yakni: pertama, aspek normatif Pemilukada, yakni penyelenggaraan teknis tahapan Pemilukada mulai dari (1) pemutakhiran DPT, (2) pendaftaran dan penetapan calon kepala daerah, (3) masa kampanye dan masa tenang, (4) distribusi logistik, (5) pemungutan suara dan rekapitulasi hasil pemungutan, serta (6) penetapan calon terpilih.

Kedua, adalah penyelesaian konflik di setiap tahapan pemilukada, yang tidak tercakup dalam kerangka normatif penyelenggaraan pemilukada, sehingga masing-masing pihak mencari jalan keluar sendiri-sendiri. Pada akhirnya kelompok politik dominan (parpol) yang akan menginisiasi skenario pengelolaan potensi 
konflik, untuk mendukung lancarny pemenangan dalam pemilukada.

Jika digambarkan dalam sebuah bagan, yang menunjukkan bagaimana relasi antara masing-masing aktor dengan potensi konflik yang ada dalam Pemilukada Kota Blitar, akan tampak pola seperti di bawah ini. Gambar. 1 Pilihan Institusi dalam Managemen

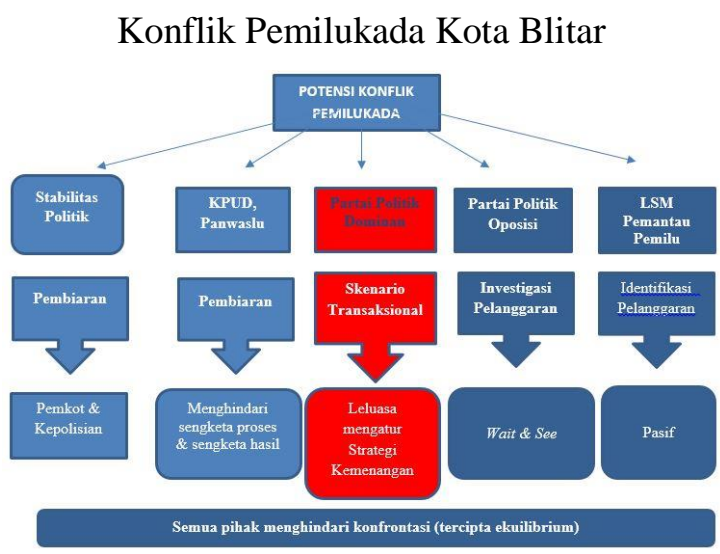

Skema tersebut menggambarkan kecenderungan pilihan sikap dan arah managemen konflik yang dipilih oleh institusi terkait pemilukada kota Blitar. Karena masing-masing insititusi akan diuntungkan jika ujung konfliknya adalah jalan damai, maka tiap istitusi cenderung memilih untuk tidak mengambil tindakan konfrontatif terhadap yang institusi atau aktor lain. Relasi utilitarian sangat kental dalam kasus ini.

Contoh yang merefleksikan pilihan pada sikap pembiaran misalnya, adalah pada kasus pencalonan kandidat. Berdasarkan penuturan beberapa pihak dalam wawancara, pengumpulan dukungan (berupa Kartu Tanda Penduduk/KTP) dari penduduk Kota Blitar bagi pencalonan pasangan perseorangan, muncul dari kekhawatiran dan langkah antisipatif bagi kandidat petahana (Samanhudi) seandainya gagal mendapatkan rekomendasi dan diusung oleh PDI-P.

Hal ini tak lepas dari cerita di lapangan, bahwa penilaian DPP PDI-P yang menilai prestasi pemerintahan rezim Samanhudi (2009-2014) tidak sebaik rezim sebelumnya (Djarot Syaiful Hidayat 20042009). Kekhawatiran ini pada akhirnya tidak terbukti dengan keluarnya surat rekomendasi pencalonan (kembali) Samanhudi oleh DPP PDI-P. Langkah pengumpulan KTP sebelumnya, menjadi skenario cadangan yang digunakan untuk mengantisipasi satu pasangan calon Walikota, yang dapat menyebabkan penundaan jadwal pemilukada Kota Blitar hingga tahun 2017.

Langkah pengumpulan KTP tersebut akhirnya digunakan untuk membuat “calon/kandidat boneka' sebagai penantang petahana dalam pemilukada Kota Blitar 2015. Calon boneka ini didaftarkan ke KPUD dengan menggunakan dukungan KTP yang telah dikumpulkan sebelumnya oleh petahana. Dengan strategi ini, meskipun parpol lain tidak mengajukan calon walikota, pemilukada Kota Blitar tetap bisa digelar pada 9 Desember 2015 karena telah memenuhi kaidah hukum dengan menyertakan dua pasangan calon walikota.

Jika partai lain di Kota Blitarterutama partai oposisi-bersikap kritis, ada kemungkinan partai oposisi menggugat keabsahan calon independen/perseorangan yang diduga kuat sebagai calon 'boneka' dari 
pasangan petahana. Misalnya, keungkinan daftar dukungan yang janggal (tanpa kelengkapan administratif, materai, atau tandatangan yang terindikasi palsu). Demikian halnya dengan Panwaslu, yang mempunyai tugas dan kewenangan melakukan verifikasi faktual keabsahan dukungan, yang-jika terbukti tidak sah-bisa berdampak pada perbaikan atau pembatalan pencalonan. Namun rupanya, baik LSM pemantau Pemilu, Parpol oposisi maupun Panwaslu Kota Blitar memilih untuk membiarkan pencalonan pasangan independen berjalan mulus.

\section{Ewuh-Pakewuh dan Pembiaran}

Tindakan pembiaran pada potensi konfllik oleh institusi terkait Pemilukada Kota Blitar menurut penulis bukan semata sikap konsensus kolektif yang tiba-tiba muncul. Sikap tersebut berbasis pada pertimbangan untung rugi jika Pemilukada berjalan lancer, tanpa sengketa dan menemukan titik ekuilibrium pada kontestasi. Bagan di atas mencoba menjelaskan hal tersebut secara umum dimana, masing-masing institusi sadar, jika terjadi konflik (sengketa) selama pemilukada berlangsung, dapat memunculkan konsekuensi politik, sosial dan psikologis yang menimpa mereka, baik secara individual maupun kelembagaan, misalnya disintegrasi atau polarisasi dalam masyarakat, selama proses pemilukada berlangsung maupun ketika kontestasi politik tersebut telah usai.

Bagan di atas linear dengan pendekatan institusionalisme pilihan rasional, yang melihat sosok manusia sebagai representasi institusi maupun kelompok sosial tertentu. Sehingga setiap tindakan mereka harus dipandang sebagai tindakan rasional sebagai pemenuhan dorongan kepentingan dan memaksimalkan keuntungan institusi/kelompok sosial yang menaungi mereka. Selain perihal ekonomi, keuntungan yang dimaksud dalam pengertian ini menyangkut pula minimalisasi reaksi negative dari actor lain di luar institusi/kelompok individu bersangkutan.

Dalam kasus pemilukada Kota Bllitar, prosedur pencalonan walikota dari jalur perseorangan memiliki masalah tersendiri. Tetapi, membiarkan persoalan di dalam prosedur tersebut adalah pilihan rasional yang pada akhirnya dipilih - dan diterima - semua pihak demi terhindar dari disintegrasi sosial. Stabilitas soasial dinilai lebih mahal jika dibandingkan dengan pengungkapan penyimpangan selama proses pengumpulan dukungan pasangan calon walikota dari jalur perseorangan, yang berpotensi menimbulkan konflik. Dalam analisis institusionalisme pilihan rasional, aktor dan kelompok melaksanakan proyeknya dalam suatu konteks yang dibatasi secara kolektif, pembatasanpembatasan tersebut terdiri dari institusiinstitusi, yaitu pola norma dan pola peran yang telah berkembang dalam kehidupan sosial dan perilaku dari mereka yang memengang peran itu.

Dalam konteks pola norma yang membatasi institusi terkait pemilukada Kota 
Blitar adalah nilai dan norma ewuh pakewuh. Ewuh pakewuh dapat dipahami sebagai sikap tidak enak hati jika harus mengambil sikap berbeda dan konfrontatif dengan pihak lain yang berbeda kepentingan dan pilihan politik. Sikap ini mendorong seseorang atau sekelompok orang memilih diam dan membiarkan penyimpangan yang dilakukan pihak lain, sepanjang masih dalam batas toleransi, karena konfrontasi adalah pilihan terakhir yang sebisa mungkin dihindari.

Norma di atas, dalam pengamatan penulis, beberapa kali dalam dialog intensif yang terjadi selama proses FGD Pemilukada Kota Blitar. Meski setiap actor atau institusi mampu mengidentifikasi kelemahan dan potensi persoalan dari masing-masing tahapan Pemilukada-baik karena tindakan secara sadar atau tidak sadar, misal karena kinerja pihak lain yang tidak optimal, tetapi sikap yang dipilih adalah pembiaran. Sebagian parpol oposisi yang hadir dalam FGD menyebut terdapat upaya 'main mata' antara petahana dengan pasangan calon walikota lain, dan indikasi upaya transaksional oleh petahana ketika pengumpulan dukungan calon perseorangan, yang diikuti pembiaran oleh KPUD dan Panwaslu. Pada akhirnya, pilihan sikap mendiamkan, membiarkan dan ewuh pakewuh yang justru dipilih oleh parpol oposisi. Tujuannya adalah terciptanya titik ekuilibrium dalam kehidupan sosial yang lebih besar, yakni situasi yang harmonis dan minim konflik.

\section{Kesimpulan}

Dari beberapa uraian di atas, terdapat beberapa poin yang menjadi kesimpulan, pertama, kontestasi politik dalam Pemilukada di Kota Blitar tahun 2015 bukan tanpa persoalan. Ada beberapa potensi konflik di tiap tahapan Pemilukada, baik pada persiapan (terkait Daftar Pemilih Tetap, pendaftaran kanddiat, penyiapan logistik), penyelenggaraan dan pasca pemilu. Hal tersebut dirasakan oleh penyelenggara pemilu karena institusi yang mempunyai tanggungjawab dalam penyelenggaraaan Pemilukada Kota Blitar. Tetapi, situasi Pemilukada di Kota Blitar yang didominasi oleh sebagian kecil elit dan partai politik pemenang Pemilu 2014, memunculkan persepsi bahwa Pemilukada di Kota Blitar minim konflik karena sudah terdapat "konsensus" bersama di antara aktor politik. Selain itu, persepsi bahwa pemenang Pemilukada sudah dapat diketahui bahkan sebelum pemungutan suara dilakukan. Pada akhirnya, meski terdapat pemungutan suara, tetapi kontestasi yang terjadi adalah kontestasi semu.

Kedua, persepsi soal konflik disadari oleh banyak stakeholder terkait Pemilukada di Kota Blitar, terutama oleh penyelenggara pemilu dan partai politik. Tetapi persepsi yang terkonstruksi di antara para aktor adalah bahwa potensi konflik dalam Pemilukada Kota Blitar 2015 sangat kecil. Untuk kebutuhan jangka panjang, hal ini menjadikan kota Blitar tidak mempunyai mekanisme 
manajemen konflik yang baik, belum ada early warning system tentang konflik Pemilukada. Padahal, kebutuhan terhadap manajemen konflik dalam pemilu, membutuhkan desain kelembagaan yang di antaranya berisi standar operasional dan interaksi kelembagaan. Disamping itu, kebutuhan terhadap manajemen konflik dalam pemilu/Pemilukada, dibutuhkan karena aktoraktor pada institusi penyelenggara pemilu (pemerintahan dan keamanan) dapat bergantiganti.

Ketiga, model manajemen konflik pada Pemilukada di Kota Blitar lebih tepat disebut sebagai 'model pembiaran' oleh penyelenggara Pemilu, Pemerintah Daerah dan pihak kepolisian. Pembiaran ini berlindung di bawah dalih; di satu sisi, Pemerintah Daerah dan Kepolisian tidak memiliki kewenangan intervensi atas proses Pemilukada, sementara di sisi lain KPUD dan Panwaslu merasa tidak mendapatkan amanat dari Undang-undang untuk mengemban peran sebagai mediator/inisiator pengelola konflik. Model pembiaran ini semakin meneguhkan kesimpulan bahwa telah ada 'konsensus' antara actor-aktor politik yang sedang berkuasa. Sehingga yang terjadi adalah, partai politik dan elit berkuasa menjadi actor dominan pengendali konflik, dengan tujuan memuluskan strategi pemenangan calon mereka dalam Pemilukada Kota Blitar.

\section{Daftar Pustaka}

Antaranews.com. 2015. Petahana SamanhudiSantoso Menangi Pilkada Kota Blitar. Diakses di http://www.antaranews. com/berita/535443/petahana-samanhu di-santoso-menangi-Pemilukada-kotablitar pada 27 Desember 2015.

Budiardjo, M. (2003). Dasar-dasar ilmu politik. Gramedia pustaka utama.

Blake, R. R., \& Mouton, J. S. (1985). The managerial grid III: The key to leadership excellence.

Cai, D., \& Fink, E. (2002). Conflict style differences between individualists and collectivists.

Communication Monographs, 69 (1), 67-87.

Clarke, P. A., \& Foweraker, J. (2001). Encyclopedia of democratic thought. Taylor \& Francis.

Fisher, Simon., et.al, 2000. Mengelola Konflik Ketrampilan dan Strategi Untuk Bertindak, terj. S.N. Karikasari dkk., Jakarta: The British Council Responding to Conflict.

Hall, P. A., \& Taylor, R. C. (1996). Political science and the three new institutionalisms. Political studies, 44(5), 936-957.

Haris, S. (2005). Mengelola Potensi Konflik Pilkada, Kompas tanggal $10 \mathrm{Me}$ $2005 i$.

Peters, B. G. (2011). Institutional theory in political science: the new institutionalism. Bloomsbury Publishing USA. 
Pruitt, D. G., \& Rubin, J. Z. (2004). Teori Konflik Sosial. Yogyakarta: Pustaka Pelajar.

Somekh, B., \& Lewin, C. (Eds.). (2011). Theory and methods in social research. Sage.

Suprapto, S. (2013). Revitalisasi Nilai-Nilai Kearifan Lokal Bagi Upaya Resolusi Konflik. Walisongo: Jurnal Penelitian Sosial Keagamaan, 21(1), 19-38.

Tempo.co. 2015. Pemilukada Sepi, Dua Calon Wali Kota Blitar Menolak Kampanye. Diakses di http://nasional. tempo.co/read/news/2015/09/02/0586 97350/Pemilukada-sepi-dua-calon-wa li-kota-di-blitar-menolak-kampanye pada 1 November 2015

Thomas, K. W. (1992). Conflict and conflict management: Reflections and update. Journal of organizational behavior, 13(3), 265-274.

Urbaningrum, A. (1999). Ranjau-ranjau Reformasi; Potret Konflik Politik Pasca Kejatuhan Soeharto, Jakarta: PT Raja Grafindo Persada.

Wallensteen, P. (2006). Understanding Conflict Resolution: War, Peace and the Global System (Arabic edition).

Wiradi, G. (2000). Reforma agraria: perjalanan yang belum berakhir. Konsorsium Pembaruan Agraria, Sajogyo Institute. 